\title{
THE FIVE BIBLICAL COMPENDIA OF JOHANN JACOB SCHMIDT
}

\begin{abstract}
Johann Jacob Schmidt, a pastor in eighteenth century Pomerania, was an author of five Biblical compendia intended as a help for a detailed study of the Bible. With the focus of the Holy Land, Schmidt provided in these compendia detailed description of the geography, history, customs, and natural knowledge including astronomy and medicine of Biblical times to show the veracity of the Bible and its relevance to any reader of any time, particularly in spiritual matters.
\end{abstract}

Keywords: Bible, Biblical interpretation, physico-theology

\section{PIĘĆ BIBLIJNYCH KOMPENDIÓW JOHANNA JACOBA SCHMIDTA}

\section{Streszczenie}

Johann Jacob Schmidt, pastor na Pomorzu w XVIII wieku, był autorem pięciu kompendiów biblijnych, które miały służyć jako pomoc w studium Biblii. Skupiając się na Ziemi Świętej, Schmidt przedstawił w tych kompendiach szczegółowy opis geografii, historii, zwyczajów i wiedzy przyrodniczej, w tym astronomii i medycyny w czasach biblijnych, aby pokazać prawdziwość Biblii i jej żywotne znaczenie dla każdego czytelnika, szczególnie w sprawach duchowych.

Słowa kluczowe: Biblia, interpretacja biblijna, fizyko-teologia

1 Dr Adam Drozdek, Associate Professor at Duquesne University; ORCID: 0000-0001-8639-2727. Correspondence address: Duquesne University, 412 College Hall, Pittsburgh, PA 15282, USA, Phone: 412.396.5897, http://www. mathcs.duq.edu/drozdek, e-mail: drozdek@duq.edu. 


\section{Introduction}

Johann Jacob Schmidt (1691-1762), a son of a pastor, received some education in academies in Frankfurt an der Oder, Wittenberg, Halle, and in Silesia, and in 1718 he became a pastor in the village of Peest (Pieszcz) and from 1747 in Palow (Pałowo) in Pomerania, in today's North-Eastern corner of West Pomeranian Voivodship (województwo zachodniopomorskie) in Poland ${ }^{2}$. Today he is remembered as an author of five Biblical compendia which had a modicum of success in his times.

Since the Bible is the foundation of all truths, as he stated in the preface of his first compendium, investigating the Bible should be everyone's occupation. However, because of the plethora of personal and geographical names, of references to long forgotten historical events, to customs obscure to today's readers, to objects of unclear functionality, Schmidt wanted to provide helpful texts to accompany readers in their Biblical studies.

\section{Biblical historicus}

The Biblical historicus was the first compendium, published in 1728 and then in $1740^{3}$. Schmidt delineated the history and geography of the world with particular emphasis on the Biblical lands. For example, when speaking about the Tatars, Scythia, and Sarmatia, Schmidt wrote that Little Tartary was inhabited by Cimmerians whose name is derived from Japhet's son, Gomer. Great Tartary in Asia together with Sarmatia or Moscow was called Scythia, that is, marksmen, because they lived from robbery; therefore, they always carried their bows and arrows with them. They come from Japhet's son, Magog ${ }^{4}$ who moved also far North; thus, even Sweden considers him as its ancestor. In particular, it seems that the land of Magog, which is a part of Scythia, is situated beneath the Caucasus mountains between the Black Sea and Caspian Sea, which partially belongs to Moscow, and partially to Turkey. Some understand the myth of Prometheus, who was chained on the mountain Caucasus, as being about Magog, who, as the Scythian father, took his seat in these mountains and dug out metals of the mountains, and invented or renewed the art of smelting. Scythians also lived in Israel in the Maccabean period and built or took over the city of Beit She'an also called Scythopolis. In Scythia also lived Rhiphatheans, whose name comes from Japhet's grandson's name, Riphath. It is believed that the apostle Andrew evangelized Scythians. It can be added that Russians consider this apostle as the one who brought the Gospel to the Russian land. When the ten tribes of Israel were taken

2 Johann Jacob Moser, Des Lexici der jetztlebenden Lutherisch- und Reformirten Theologen in und um Teutschland, zweyter Theil (Züllichau [= today's Sulechów in Poland]: Benjamin Gottlob Frommann, 1741), 943-946; Johann Anton Trinius, Beytrag zu einer Geschichte berühmter und verdienter Gottesgelehten (Leipzig: Carl Ludwig Jacobi, 1751), 552-558; Wolfgang Eckart, "Die Wissenschftstheologie des Johann Jacob Schmid (1691-1762): Anmerkungen zur Literaturgeschichte Ostpommerns", Pommern: Kunst, Geschichte, Volkstum 20, 4 (1982): 1-9.

3 Already in this book "he showed a skillful presentation, great diligence, and humility", Auserlesene theologische Bibliothec, part 25 (Leipzig: Joh[ann] Friedr[ich] Brauns sel[igen] Erben, [1724-1736]), 1071.

4 Johann Jacob Schmidt, Biblischer historicus (Leipzig: Jacob Schuster, 1740), 18. 
away to Media, Armenia, and Iberia, they gradually moved further into the remote lands of Scythia and the Tartary; hence, some want to find there all the names of the tribes Dan, Naphtali, Zebulun, etc. ${ }^{5}$

Geographical descriptions were not detached reports on geography of various regions, but they carried a theological message. For example, Schmidt said that the description of Palestine shows God's wisdom in distinguishing Israelites from other peoples, God's providence in exact division of this land between tribes, God's truth in keeping His promises made to Abraham, and God's justice in punishing the evildoing of inhabitants ${ }^{6}$.

The chronological part of the Historicus contains a description of the way of measuring time, but also the chronology of Biblical events. For example, the reader learns that the world was created in fall, 1657 years before the flood and 4003 years before the birth of Christ $^{7}$. The world was created in fall, since all was created perfect (as also later argued, although hesitatingly, in the Physicus $^{8}$ ) and the land was full of food. Among the oldest nations the year started in the fall and so it did for the Israelites (Ex. 23:16) ${ }^{9}$. The flood also started in the fall ${ }^{10}$. Dec. 25 was chosen by the fathers of the church for the birth of Christ to make it easier for pagans to accept Christ since they considered 25th of Dec. natalis victus, the fest of the return of the sun. The date was falsely believed to be about Dionysius, so the Eastern fathers chose 6th of January, but Christ was probably born in the beginning of the fall ${ }^{11}$.

In discussing the Biblical genealogies, Schmidt said that because Matthew wanted to show how the Messiah was born from the promise, he started his genealogy of Christ from Abraham sometimes leaving out some members of the genealogy. Luke, on the other hand, wanted to show that Christ came from forefathers by flesh; thus, he started from Eli, Mary's father and ended with Adam ${ }^{12}$. Joseph was 80 or 73, Mary was 15, he had been married before and had children. Cleophas married the widow of Alphaeus "who became Mary" so that Christ's mother is called a sister (J. 19:25) and gave Cleophas three sons (Mt. 13:55). Her son from Alphaeus was Jacob/James Alphaeus, little Jacob (Mk. 15:40), called Christ's brother (Gal. 1:19) ${ }^{13}$. Since Mary stemmed from Salomon, so Jesus was a prince ${ }^{14}$.

Schmidt provided also the universal history with a fair amount of information added from the lands neighboring Palestine: Greece, Egypt, Persia, etc., particularly from more recent times.

\footnotetext{
5 Schmidt, Biblischer historicus, 19.

6 Schmidt, Biblischer historicus, 94.

7 Schmidt, Biblischer historicus, 195, 199.

8 Schmidt, Biblischer historicus, 21.

9 Schmidt, Biblischer historicus, 200.

10 Schmidt, Biblischer historicus, 202.

11 Schmidt, Biblischer historicus, 233.

12 Schmidt, Biblischer historicus, 256-257.

13 Schmidt, Biblischer historicus, 264.

14 Schmidt, Biblischer historicus, 265.
} 
When speaking about writing, Schmidt considered Hebrew to have been the oldest language already spoken by Adam who also introduced the Hebrew alphabet which was being perfected until Moses ${ }^{15}$. The content of the Scriptures was revealed to the elected scribes and God "directed their plume/pen"16. The last statement does not quite square with his view that an error of the scribe is allowed, and thus, in Luke, there is Cainan/ Kenan between Arphachsad and Salah, the name which is removed from the Septuagint and from some New Testament codices ${ }^{17}$. Schmidt may contend that God directed the pen of the original writers of the Bible, but the generation of copyists was apparently not under direct divine supervision.

Schmidt also said that Homer took much material from the Bible to include it in the Iliad and Odyssey, also Numa, Pythagoras, Plato, Aristotle based at least some of their statements on the Bible ${ }^{18}$. This was not an unusually made claim, although the documented knowledge of the Greeks about the Jews is very late and dates to the times of Theophrastus, the successor of Aristotle in the Academy.

Schmidt described various Biblical personalities using mainly the information extracted from the Bible. For example, he said about Samuel that he was the son of Hanna and Elkana, whose name means "received from God by prayer". At about the age of 5, Samuel became a servant of God in Silo. He was a good musician who passed this art to his children. From about the age of 12 , he received a call from God and became His prophet $^{19}$. At about the age of 30, after the death of the priest Eli, he became a judge in Israel. By the people's demand, he anointed a king of Israel, who was Saul. Samuel lived in Ramah and was asked by people for advice. To his noteworthy acts belong his miracle-bringing prayer; his order concerning Levitical service ${ }^{20}$; and the anointment of Saul. He suffered because of the actions of his sons, because of the stubbornness of people, and because of the rejection of Saul. Samuel died at about the age of 70 and was buried in Ramah. After his death, satan appeared in his form to Saul. Samuel authored some books of the Bible (1 Chron. 29:29), although it is uncertain which ones, probably Judges $^{21}$, Ruth ${ }^{22}$, and the two Samuel books ${ }^{23}$.

When performing a modicum of Biblical criticism, Schmidt said that Matthew's gospel was written first ${ }^{24}$, which is the view largely rejected today. Mark's gospel, he said, was written long after Matthew's gospel and Mark did not rely on Peter; his gospel came

\footnotetext{
15 Schmidt, Biblischer historicus, 612-613; cf. also the Geographus, 45-46.

16 Schmidt, Biblischer historicus, 615.

17 Schmidt, Biblischer historicus, 252.

18 Schmidt, Biblischer historicus, 630.

19 Schmidt, Biblischer historicus, 644.

20 Schmidt, Biblischer historicus, 645.

21 Schmidt, Biblischer historicus, 646.

22 Schmidt, Biblischer historicus, 648.

23 Schmidt, Biblischer historicus, 649.

24 Schmidt, Biblischer historicus, 769.
} 
directly from the Holy Spirit ${ }^{25}$. Luke wrote after Matthew and Mark ${ }^{26}$. Schmidt ascribed the authorship of the Epistle to the Hebrews to Paul ${ }^{27}$, which is the view accepted by the Eastern church.

Schmidt described various ancient customs; for example, he said that maidens in the Levant not only are withdrawn/secluded and live in separate rooms, but when they go out, they cover their faces and even the entire body and those who uncovered themselves in public were considered harlots. Usually all women had a separate room from men, whereby Bathsheba did not know that Adonijah proclaimed himself a king ${ }^{28}$. About buildings Schmidt said that the first houses were built by Cain when building the city of Enoch. Houses in the East were not built too close to one another and they were built primarily as shelters from the heat of the day. Roofs were flat, so that grass frequently grew on them. There was an easy access to them and they had a protective rail ${ }^{29}$. The beauty of the house was not in its adornments, but in its form. Well smelling wood was used for rich houses, such as cedar. Windows and doors were covered with curtains ${ }^{30}$.

In all this, Schmidt made a strong claim that in Moses' books there is the essence (Inbegriff) of all science: theology, jurisprudence ${ }^{31}$, medicine, metaphysics, physics: according to some, Moses discovered three principles of nature: materia prima (water), spiritus plasticus (natural power to do everything in everything), and the universal organon (light of fire, the source of all movement); Moses also spoke about the principles of meteorology $y^{32}$, astronomy, lithology, zoology, mathematics ${ }^{33}$, mechanics, ethics, politics, economics $^{34}$, history, philology, and $\operatorname{logic}{ }^{35}$. In fact, the view that the Bible was in many respects ahead of science was frequently defended, very strenuously, for example, by Bernard Nieuwentijt.

\section{Biblical physicus}

Within three years, Schmidt published his Biblical physicus in 1731 which was reissued in 1748 and a Dutch translation came out in $1769^{36}$. As he stated on the opening page of the preface, he was giving here a "small book" to shed some light on many Biblical verses with the help of natural sciences. An over 600-page book could be considered small when

25 Schmidt, Biblischer historicus, 773.

26 Schmidt, Biblischer historicus, 776.

27 Schmidt, Biblischer historicus, 805.

28 Schmidt, Biblischer historicus, 887.

29 Schmidt, Biblischer historicus, 899.

30 Schmidt, Biblischer historicus, 900.

31 Schmidt, Biblischer historicus, 624.

32 Schmidt, Biblischer historicus, 625.

33 Schmidt, Biblischer historicus, 626.

34 Schmidt, Biblischer historicus, 627.

35 Schmidt, Biblischer historicus, 628.

36 Johann Jacob Schmidt, Biblischer physicus (Leipzig: Jacob Schuster, 1748). 
compared with the 1100 pages of the Historicus. As he continued in the preface, the book is a practical introduction to the knowledge of the Creator from the investigation of properties, to the uses and disadvantages of natural things, and also to the symbolic meaning of natural things used in similes ${ }^{37}$. In fact, the book presents Schmidt's own views concerning primarily physics and astronomy.

As he wrote, the Bible contains truth and God could not, as some Cartesians claim, express Himself using the erroneous language of the mob. There are truths of the senses and scientific truths or truths of causes, the former fitting the Scriptures, the latter being of no concern to the Scriptures and thus should not be searched. The goal of the Bible is to direct people to happiness through the faith in Christ. "The Holy Scripture does not teach us that which is possible for us to learn through reason, but it leaves such effort to the sages, cf. Koh. 1:13". Another goal is to show what by the investigation of nature cannot be learned ${ }^{38}$, e.g., the creation of the world, the creation of Eve from Adam's rib, the fall, the flood, and the like ${ }^{39}$. The truth of the senses leads to the name "solar eclipse", even though the sun is not really eclipsed. The Scripture calls the moon a light ${ }^{40}$, since this is the way it appears to the eye; it is the truth of the senses. There is only an apparent contradiction between the Ptolemaic system and the claims of "messieurs Copernicans" in respect to the motion of the sun since these are truths of two different categories ${ }^{41}$.

The existence of God can be inferred "from the makeup of the whole world, in particular, from the order in which time and space as to their general content are filled, after it can be without contradiction concluded by the light of reason that when a person perceives that the world in the appearance of its reality, i.e., as it had been brought about, is not a necessary but accidental entity", and, as such, its cause is outside of it, the first and necessary cause, God. The world is a mirror of the divine perfection from which we can have natural knowledge of God ${ }^{42}$. It is also a mirror of the freedom of God's will.

Time and space are infinitely divisible and each portion of time and space is filled with somethings, so the world is a mirror of an infinite and immeasurable knowledge of God ${ }^{43}$, a mirror of the most perfect wisdom of $\operatorname{God}^{44}$, of the infinite and immeasurable power of God ${ }^{45}$, of the goodness of God, of the justice of God, of the providence and the rule of $\mathrm{God}^{46}$.

37 One reviewer considered this book to be "useful to all Christians, particularly to beginning preachers", Fortgesetzte Sammlung von alten und neuen theologischen Sachen auf das Jahr 1733 (Leipzig: Joh[ann] Friedr[ich] Brauns sel[igen] Erben [1733]), 477.

38 Schmidt, Biblischer physicus, 4.

39 Schmidt, Biblischer physicus, 5.

40 Schmidt, Biblischer physicus, 6.

41 Schmidt, Biblischer physicus, 7.

42 Schmidt, Biblischer physicus, 12.

43 Schmidt, Biblischer physicus, 13.

44 Schmidt, Biblischer physicus, 14.

45 Schmidt, Biblischer physicus, 15.

46 Schmidt, Biblischer physicus, 16. 
The world does not have its being from itself and thus it cannot maintain itself $f^{47}$, so God constantly maintains its existence ${ }^{48}$, so that there is no natural principle guiding the world, for there is only the will of $\operatorname{God}^{49}$; there are no secondary causes, since the causality belongs to God only; God directly causes rain, lightening, the growth of plants and animals, the growth of a fetus. God causes all through natural means. The creation of the macro world is an image of new creation which the triune God undertakes daily with the micro world, a man ${ }^{50}$.

Because of the omnipresence of God, all natural events and phenomena are really manifestations of God's presence. For example, through the changes of the four seasons "we can see and feel how God extraordinarily frequently rules over the course of nature and through weather, as it were, directly reveals his presence". There are fruitful and fruitless years depending on weather, but it is unknown why God makes one or the other ${ }^{51}$.

Snow comes out from "frozen mists/vapors that in mild air becomes soft and when they become fluid, and when they solidly fall together, they fall down in large groups". Heavy snow comes from the break of a cloud. The Bible says that snow is maintained by God; that snowflakes are a wonderful artwork of God; that it is cold; that water from snow purifies the skin ${ }^{52}$; that snow is throughout the year on mountaintops. The Bible also states that snow is useful since it brings rain to which it can be added that in cold countries it covers the ground to protect seeds. The Biblical testimony says that because of its coldness, snow can be harmful; that God used it to punish the godless; that it is an image of transitoriness ${ }^{53}$.

Thunder and lightening are a wonderful work of the majestic God, of His power, wisdom, rule, and providence; God uses them as a warning, scare, and punishment ${ }^{54}$. They are the work of His wrath and justice, and goodness when they cool down temperature. Uses exceed harms ${ }^{55}$.

When natural phenomena such as thunder come from natural causes, they carry no meaning of God's grace or wrath, since it is against God's perfect wisdom to set natural signs which man for no reason should see as a connection between things and guess the meaning as he sees that clouds are the sign of rain; the Scriptures already very convincingly speak about good and evil; reason also teaches us that God rewards virtue and punishes vice; no need to announce it through atmospheric phenomena; it is against God's wisdom to show a sign everywhere when it would be directed against a particular

\footnotetext{
47 Schmidt, Biblischer physicus, 23.

48 Schmidt, Biblischer physicus, 24.

49 Schmidt, Biblischer physicus, 24.

50 Schmidt, Biblischer physicus, 25.

51 Schmidt, Biblischer physicus, 72.

52 Schmidt, Biblischer physicus, 102.

53 Schmidt, Biblischer physicus, 103.

54 Schmidt, Biblischer physicus, 118.

55 Schmidt, Biblischer physicus, 119.
} 
state, city, or person ${ }^{56}$. Nothing certain can be derived from experience and there is nothing in the Scripture about such phenomena being signs; it even speaks against such superstition ${ }^{57}$. God uses some phenomena to punish sinners, but these phenomena are not signs of God's wrath; it is people who ascribe such a meaning to them ${ }^{58}$.

Water points to God's omnipotence: the distribution of water over the earth; if its particles were smaller, it would be like air and no fish could live in there, no ship travel would be possible ${ }^{59}$. Water shows God's wisdom ${ }^{60}$ : if there were more clouds, air would be colder, there would be more rain and snow, land would be flooded; if there were fewer clouds, there would be droughts and lack of fruits, etc. Water points to God's goodness since water is used for drinking ${ }^{61}$, washing, it is a place for the fish, etc. ${ }^{62}$ It is not quite clear where water in sources and wells comes from. Nothing is annihilated in nature and water just circulates (Koh. 1:7), although it is not exactly known how ${ }^{63}$. Most likely, water comes from dew, rain and snow and from vapors coming from underground channels ${ }^{64}$. The existence of underground channels as the primary source of water in sources, rivers, and wells was promoted in the 18th century, the channels that guided water from the seas to these sources. Various mechanisms were proposed as to how this water became desalinated along the way.

God's blessing is visible in the flora of the earth and Schmidt described many uses of various plants. On this occasion, he also touched upon the two trees in the Eden. In his view, the tree of life was created to strengthen like medicine human innate immortality or to maintain humans in constant health and keep weaknesses and the accidents of the old age away from them. The tree of the knowledge of good and evil or of perceiving/ sensing good and evil was for man to look at and to remind him what is good in order to keep God's commandments ${ }^{65}$.

God's hand is also clearly manifested in the fauna. "The body of animals, as in humans, scrutinized not only in its entirety, but also in particular parts, is an incomparable artwork of the almighty Creator, the omniscient Maker of all things, [it is] a hydraulic-pneumatic machine, such an air- and water-craft, which shows before our eyes the perfections of God in clear mirror and extols them". For example, the eye infinitely surpasses what humans could build, although Schmidt did not back it up by a description of the eye as often done in physico-theological books ${ }^{66}$.

\footnotetext{
56 Schmidt, Biblischer physicus, 136.

57 Schmidt, Biblischer physicus, 127.

58 Schmidt, Biblischer physicus, 128.

59 Schmidt, Biblischer physicus, 147.

60 Schmidt, Biblischer physicus, 148.

61 Schmidt, Biblischer physicus, 149.

62 Schmidt, Biblischer physicus, 150.

63 Schmidt, Biblischer physicus, 158.

64 Schmidt, Biblischer physicus, 160.

65 Schmidt, Biblischer physicus, 303-331.

66 Schmidt, Biblischer physicus, 404.
} 
No creature should be despised, since it is a creation of God. "The smallest worm shows the knowledge and wisdom and omnipotence of the Creator no less than the largest animals and other bodies of this world". We admire the work of God not only in the elephant but also in an ant and in a worm ${ }^{67}$. And yet, as he let slip out, nothing is more contemptuous than a flea ${ }^{68}$.

\section{Biblical mathematicus}

The Biblical mathematicus, published in 1736 and then in $1749^{69}$ is discussing the use of numbers in various areas primarily as measuring units and to see whether the numbers used in the Bible in various contexts can be trusted. In all this, he wanted to show that "Christian philosophers well recognize that [the Bible] in no way contradicts philosophical and mathematical truths" ". However, Schmidt started with a philosophical discussion of numbers with a fair dosage of mystical insights.

Familiarity with numbers is inborn ${ }^{71}$. Zero is nothing by itself, but when 1 is put in front of it, there is number $10^{72}$ : we are nothing by ourselves, but when God writes "to our natural zeros a 1 or 2 or more". we become something ${ }^{73}$. Following Pythagoras, it is stated that "one is the beginning and the end of all numbers, so it measures all numbers, but itself is not a number; it is neither even nor odd and it is and makes both: it is not generated by any other [number] and generates none other (namely through Multiplication)" "74. It is an image of the Divinity; "one" leads us to God. God is one ${ }^{75}$. Two is the first number derived from one ${ }^{76}$; it is an image of man who comes from God, the true one(ness). Through Christ, the two become one, God and man, Christ and the soul ${ }^{77}$. Three is the first perfect odd number; it has the beginning, the middle, and the end, each as large as the others and leads with number 7 among pagans to the title of holiness. It is the number of the triune God, a perfect number. There are 3 primary Christian virtues (1 Cor. 13:13), 3 powers of the soul (intellect, will, and memory), and 3 major sins ${ }^{78}$. Four has two halves, 2 and 2, which added or multiplied give 4 and thus it is the first perfect even number. The name of God has 4 letters in many languages; there are 4 corners

\footnotetext{
67 Schmidt, Biblischer physicus, 545.

68 Schmidt, Biblischer physicus, 576.

69 Johann Jacob Schmidt, Biblischer mathematicus (Züllichau: Gottlob Benjamin Frommann, 1736).

70 Schmidt, Biblischer mathematicus, 160.

71 Schmidt, Biblischer mathematicus, 2.

72 Schmidt, Biblischer mathematicus, 90, 93.

73 Schmidt, Biblischer mathematicus, 94.

74 Johann Ludwig Hocker, Mathematische Seelen-Lust, part 1 (Frankfurt: Samuel Tobias Hocker, 1712), 93.

75 Schmidt, Biblischer mathematicus, 12.

76 Schmidt, Biblischer mathematicus, 13.

77 Schmidt, Biblischer mathematicus, 14.

78 Schmidt, Biblischer mathematicus, 15.
} 
of the world, 4 main winds, 4 temperaments, etc. ${ }^{79}$ Five multiplied by an odd number generates 5 in the unit part, $3 \cdot 3=15,5 \cdot 7=35$, etc. ${ }^{80} \mathrm{Six}$ is in 10 the first perfect number since $1+2+3=6$ proclaiming the perfection of the works of the Creator since the world was created in 6 days $^{81}$. 666 is the number of the beast; 6 is the number of man created in the likeness of God, so 6 is an image of 3, since it is composed from numbers 3, i.e., from 3 and 3, so is man created on the 6th day the most perfect artwork of God, an image of the triune God. 6 is also the number of the beast since man after the fall fell into bestial crudeness for which Christ was sentenced at the 6th hour of the 6th day (J. 19:14-16). As to the interpretation of 666 , the number underscores the monstrosity of the beast which is described as having 7 heads, 10 horns with 10 crowns; thus, the beast has 6 additions heads (Ap. 13:1), each head has 10 horns, 60 in total in these additional heads, and each horn has 10 crowns, 600 in total in these heads, hence 666, and the beast is no particular person but "a large crowd and the society of the godless" that is not generated by any number and does not generate any, i.e., it is not divisible by any number (never mind 1) and does not divide any number $\leq 10$, so 7 has no mother and no children being born from 1 , the source of all numbers ${ }^{83}$. Eight is the first cube, [8=23] and it is the symbol of death since the second digits of the sums of the digits forming its first 8 multiples decrease: 8 and 8,16 and $1+6=7,24$ and $2+4=6,32$ and $3+2=5,40=$ $4+0=4,48=4+8=12$ and 1 is discarded, 56 and $5+6=11$, and 1 is discarded, 64 and $6+4=10$ and 1 is again discarded (today, we would say that the sum of the two digits is divided modulo 10$)^{84}$. Nine is the first square of an odd number, which is 3 [9=32]. 9 is the symbol of stability since the sum of the digits forming its first 9 multiples add up to 9: 9 and 9,18 and $1+8=9,27$ and $2+7=9$, etc. ${ }^{85}$ Ten is the borderline stone marker of all digits; $10=1+2+3+4$; it is the number of perfection ${ }^{86}$.

Schmidt included many numerical investigations related to various events or phenomena. For example, in 215 years in Egypt, Israelites grew from 70 to 600 thousand males, which is ca. 3 million people ${ }^{87}$; the other 215 years were spent on pilgrimage in and outside Egypt ${ }^{88}$. Is such a population explosion possible? If in 50 years, each man would have 10 sons, then from 55 grandsons of Jacob there would be in 200 years 550 thousand

\footnotetext{
79 Schmidt, Biblischer mathematicus, 18.

80 Schmidt, Biblischer mathematicus, 19.

81 Schmidt, Biblischer mathematicus, 20.

82 Schmidt, Biblischer mathematicus, 20, 30.

83 Schmidt, Biblischer mathematicus, 22.

84 Schmidt, Biblischer mathematicus, 28.

85 Schmidt, Biblischer mathematicus, 29.

86 Schmidt, Biblischer mathematicus, 30.

87 Schmidt, Biblischer mathematicus, 40.

88 Schmidt, Biblischer mathematicus, 39.
} 
males $(=55 \cdot 104)^{89}$. If each man had 5 sons in 30 years, then in 7 th generation (210 years) there would be $55.57 \approx 4.3$ million males ${ }^{90}$. So, yes, it is possible.

There are more blessings than the number of the grains of sand in the volume of the entire earth" ${ }^{91}$. There is a spiritual message derived from it: "Stand still here, my soul, and admire in the deepest humility your great inability to comprehend the multitude of God's blessings. Oh, how large a sum/amount it is for you! If you should count it, it would be larger than the sand" (Ps. 139:17-18). You have to find out an incomprehensible number, the number which exceeds in quantity not only the sand by the sea, but all the smallest particles of the whole earth. But not only the earth is full of the goodness of the Lord (Ps. 34:5) and his kindness (Ps. 104:24), but his goodness extends as far as the heavens (Ps. 36:5); it is above the heavens, says David (Ps. 57:11)" ${ }^{\prime 92}$. In fact, Schmidt referred to the assessment provided by Archimedes in the Sand reckoner, which says that there are 1063 grains of sand in the universe as known to Archimedes (36). However, only God knows an exact number of the grains of sand ${ }^{93}$.

There is a problem with the size of the sea, a large vessel used in the tabernacle. The Biblical assessment says that its diameter was 10 cubits and the circumference was 30 cubits, which would make the number $\pi$ to be equal to 3 . Noteworthy, Nieuwentijt thought that the sea was of hexagonal shape. Schmidt proposed that the circumference was measured with the cord that was not taken around the top, but around the middle of the outer surface of the bell-shaped sea ${ }^{94}$ since the rim was covered with bumps ${ }^{95}$.

Some numerical aspects of events are deflected by not treating them literally. For example, the problem, how could David put on his head a crown of 1 talent $=200$ pounds was solved by proposing that this was possible if it was the way of saying that the crown was worth 1 talent of gold (2 Sam. 12:30) ${ }^{96}$.

Among the many numerical investigations, many of them are of serious and interesting value, for example, how many animals were offered each year ${ }^{97}$ or how much stuff came to Solomon's court annually ${ }^{98}$, but occasionally they became somewhat frivolous, for instance, what was the weight of Absalom's hair cut once a year (2 Sam. 14:26) ${ }^{99}$ or can eyes have bewitching power ${ }^{100}$.

\footnotetext{
89 Schmidt, Biblischer mathematicus, 43.

90 Schmidt, Biblischer mathematicus, 40.

91 Schmidt, Biblischer mathematicus, 99, 101.

92 Schmidt, Biblischer mathematicus, 103.

93 Schmidt, Biblischer mathematicus, 39.

94 Schmidt, Biblischer mathematicus, 160.

95 Schmidt, Biblischer mathematicus, 161.

96 Schmidt, Biblischer mathematicus, 207.

97 Schmidt, Biblischer mathematicus, 46.

98 Schmidt, Biblischer mathematicus, 52.

99 Schmidt, Biblischer mathematicus, 208.

100 Schmidt, Biblischer mathematicus, 597.
} 
Astronomy shows God's providence and leads people to greater appreciation of God's omnipotence $^{101}$. The investigation of the indescribably large space and of the number of stars makes people realize how small they are ${ }^{102}$. In the Physicus, Schmidt stated that the majesty of God was manifested in the infinity of space in the world ${ }^{103}$. Now, in the retraction of this statement, he said that the world was not infinite. The size of the universe shows that the earth is not the only reason for the existence of this universe nor was the universe created for humans alone as was thought before. Therefore, there must be other creatures for whom other planets and stars were created even though the Bible is silent about $\mathrm{it}^{104}$.

The Copernican system was accepted in Schmidt's times by most scholars ${ }^{105}$, but the Copernicans did not show that this system is the only one possible and there are some doubts cast on the system, "so we find ourselves not yet forced to come to its side all the more that the Sacred Scripture agreed with no system thought out and constructed by humans", but speaks about heavens so that people can praise God, not that they should resolve their philosophical differences ${ }^{106}$.

Heaven is a subtle, fluid entity much rarer than air ${ }^{107}$. The heaven is likely spherical since sphere is the most perfect figure ${ }^{108}$. God resides with angels in the empyrean, the third heaven, Abraham's womb ${ }^{109}$. Closer to earth, there is the moon on which, there is water, rivers, seas, thick air ${ }^{110}$, vegetation, animals, and inhabitants ${ }^{111}$. Also, the planets in the solar system are inhabited ${ }^{112}$. In fact, the stars are the suns with their own planets which are also inhabited and these inhabitants recognize the Creator and praise His wonders $^{113}$, the rational beings, who, like humans had been created on the sixth day, as remarked in the Physicus ${ }^{114}$. In the 18th century, the view of the multiplicity of inhabited worlds was fairly popular as opposed to earlier times, and the argument was that precisely this plurality pointed to God's power and wisdom at the cost of rejecting the special status of humanity in the cosmos.

\footnotetext{
101 Schmidt, Biblischer mathematicus, 389. 102 Schmidt, Biblischer mathematicus, 390. 103 Schmidt, Biblischer mathematicus, 26. 104 Schmidt, Biblischer mathematicus, 397. 105 Schmidt, Biblischer mathematicus, 399. 106 Schmidt, Biblischer mathematicus, 400, 438; the sentiment already expressed in the Historicus, 178. 107 Schmidt, Biblischer mathematicus, 401; cf. the Physicus, 28. 108 Schmidt, Biblischer mathematicus, 406. 109 Schmidt, Biblischer mathematicus, 410. 110 Schmidt, Biblischer mathematicus, 456. 111 Schmidt, Biblischer mathematicus, 457. 112 Schmidt, Biblischer mathematicus, 465. 113 Schmidt, Biblischer mathematicus, 430, 474; the Physicus, 21. 114 Schmidt, Biblischer mathematicus, 21.
} 


\section{Biblical geographus}

The Biblical geographus focuses on the geography of the Holy Land and of the world. Geography was already presented in the Biblical historicus on some 180 pages. Schmidt basically rewrote this part by adding significantly more material and also maps that were lacking in the Historicus, producing an almost 900-page book ${ }^{115}$.

He opened the book with some wide perspective concerning the earth. He said that the earth is the most eminent celestial body on which God applied most time and effort ${ }^{116}$, which is an attempt to give the earth and humanity a special status in the cosmos, although it is not quite clear what this special status would be. This time, the tree of life and the tree of the knowledge of good and evil were probably forests ${ }^{117}$. By looking at the latter, man should be reminded about keeping God's commandments ${ }^{118}$.

The geographical material from the Geographus is included, but largely reworked. For example, about the Tartars and the Scythians we read now that the land of Uzbeks at the Caspian Sea with the main city of Maracanda/Samarkand was considered to be the land of Great Tartary ${ }^{119}$ and that the Great Tartary was ruled by China ${ }^{120}$. The land from the Black Sea and Caspian Sea extending North up to the Arctic Ocean was called Scythia. Their name may come from Persian saca or may mean marksmen since they used arrows in hunting and robbing. Their forefather was Magog, a son of Japhet, so Scythians are meant by the land of Magog. Magog first settled in the region of Caucasus Mountains and his descendants spread northwards. The myth of Prometheus is sometimes understood to be about Magog who mined metals in these mountains. Scythia was later divided into Sarmatia and Scythia ${ }^{121}$.

\section{Biblical medicus}

The Biblical medicus is the final installment in Schmidt's series of his compendia ${ }^{122}$. He regarded it, as he stated in the preface, as the second part of the Biblical physicus in which he presented God's marvels in the flora and the fauna, with only a few mentions of humans, and humans became the topic of the Medicus, the humans who are the last

\footnotetext{
115 Johann Jacob Schmidt, Biblischer geographus (Züllichau: Gottlob Benjamin Frommann, 1740). By the time of the publication of the Geographus, Schmidt is considered "well known in the world of scholars", Neue Zeitungen von gelehrten Sachen auf das Jahr 173942 (1739): 376.

116 Schmidt, Biblischer geographus, 5.

117 Schmidt, Biblischer geographus, 40.

118 Schmidt, Biblischer geographus, 41.

119 Schmidt, Biblischer geographus, 449.

120 Schmidt, Biblischer geographus, 478.

121 Schmidt, Biblischer geographus, 850-851.

122 Johann Jacob Schmidt, Biblischer medicus (Züllichau: Johann Jacob Dendeler, 1743; followed by a 1776 Dutch translation).
} 
and most perfect creation of God, an artwork of the Master of all that is beautiful, the microcosm $^{123}$.

Animals are brought from the earth with their souls, so the souls are particles of earth ${ }^{124}$, but the human soul has its origin directly from God ${ }^{125}$. New souls are generated by humans 126; "the soul of the body is the fruit reproduced by the soul [singular] of the procreating parents"127. The soul has no parts, and thus it is immortal, but God could destroy it ${ }^{128}$. Another proof of the soul's immortality is the fact that people are born with the desire for immortality ${ }^{129}$, and presumably, a good God could not instill in human souls such a desire if it were not possible to fulfil it.

When describing the wondrous makeup of the human body, in spite of the sentiment that "Man is nothing whose body is a representation of death" 130 , Schmidt considered the head to be "the main seat of the soul and the workshop of intelligence, memory, and all affective motions"131 and the brain, "the precious seat of the souls, the right workshop of senses" 132 . The face is the mirror of the soul ${ }^{133}$, and the eye "is undoubtedly one of the noblest parts of the body, and there is almost nothing in the whole anatomy that is so artful and admirable as the beautiful structure of the human eye, so that it is a real marvel of the almighty Creator, and can be called an artful masterpiece of his divine wisdom"134. Interestingly, genitals are "an astonishing work of art and masterpiece of the almighty Creator, from which his extraordinary wisdom and goodness shine, all the more since they are the tools by which are conceived and born more and more people as the noblest and most perfect creatures of God and what is still more, such souls, who live under him here and there in his kingdom and serve him"135.

Before the flood, "Nature was one among themselves [people], and also the first inhabitants of the earth were freed from all the internal diseases with which the human race was afflicted after that time"136 (665). Sin is the main cause of illnesses ${ }^{137}$ (365) and as such, they belong to the kingdom of satan and of darkness, so they are often the work of impure spirits; after all, satan is called the spirit of illness (Lk. 13:11) ${ }^{138}$; the

123 Schmidt, Biblischer medicus, 10. 124 Schmidt, Biblischer medicus, 41. 125 Schmidt, Biblischer medicus, 42. 126 Schmidt, Biblischer medicus, 44. 127 Schmidt, Biblischer medicus, 45. 128 Schmidt, Biblischer medicus, 48. 129 Schmidt, Biblischer medicus, 49. 130 Schmidt, Biblischer medicus, 355. 131 Schmidt, Biblischer medicus, 169. 132 Schmidt, Biblischer medicus, 174. 133 Schmidt, Biblischer medicus, 178. 134 Schmidt, Biblischer medicus, 187, 200.

135 Schmidt, Biblischer medicus, 289.

136 Schmidt, Biblischer medicus, 665.

137 Schmidt, Biblischer medicus, 365.

138 Schmidt, Biblischer medicus, 367-368. 
secondary causes of illnesses are passions ${ }^{139}$, bad air ${ }^{140}$, the quality and amount of food ${ }^{141}$. Descriptions of innumerable illnesses are provided. For example, dysentery "is, in fact, a real eating up and deterioration of the intestines, which often forces man to defecate, whereby he gives off a lot of slimy matter, blood and pus with great pain and violent belly ache"142. Although "the beginning of our well-being and recovery must be originated by him, the only good God, from whom all good gifts come down to us"143, true to the title of the book, some remedies are provided ${ }^{144}$.

As in the Physicus, Schmidt wanted to show that the developments of science, in particular in the human anatomy and physiology and in medicine, not only did not prove the Bible wrong, but accentuated its veracity and proved the Bible deniers wrong ${ }^{145}$.

\section{Summary}

As a theologian, Schmidt saw the Bible as the primary way leading people to God. Although he devoted so much attention to science of his times, he treated it as a means to a better understanding of the Bible. Not infrequently, however, particularly in the Physicus and the Medicus, he used the tone of physico-theology that was interested in proving the existence and the attributes of God from the structure and orderliness of the universe and everything in it. For physico-theologians the makeup of the universe and everything in it was the primary, even only, proof of the existence of God and consequently, the proof of God's attributes. For Schmidt, the existence of God did not require any proof. Physico-theology was for him the means of bringing his readers closer to God by making them appreciate God's wise and providential work in nature and also to appreciate the profundity and the wisdom of the Bible ${ }^{146}$. He wanted his readers to explore the Bible and give them a hand in understanding its statements related to the mundane aspects of life and to the lofty spiritual life, the statement which may be couched in the language that required philological elucidation, which Schmidt generously provided, in the context of

139 Schmidt, Biblischer medicus, 369.

140 Schmidt, Biblischer medicus, 370.

141 Schmidt, Biblischer medicus, 372.

142 Johann Hübner, Curieuses und reales Natur- Kunst-Berg-Gewerck- und Sadlungs-Lexicon ([Leipzig]: Joh[ann] Fried[rich] Gleditsch, 1714), 501.

143 Christian Friedrich Richter, Die höchst-nöthige Erkenntniß des Menschen, sonderlich nach dem Leibe und natürlichem Leben (Leipzig: Joh[ann] Friedrich Gleditschen, 1737), 890; Schmidt, Biblischer medicus, 751.

144 See also Gisela Dehmel, Die Arzneimittel in der Physikotheologie (Münster: Lit Verlag, 1996), ch. 7.

145 "In particular, it deserves much praise the effort that Mr. Schmidt made to illuminate and justify according to the physical and medical principles the biblical truths, which scoffers of the revelation attacked and thought to have weakened using arguments from medical science", Pommerische Nachrichten von gelehrten Sachen 1, 84 (1743): 693.

146 As hoped by a reviewer of the Medicus, this work will serve the readers "who allow themselves be inspired to greater worship God", [Gottlob Benjamin Frommann], Zuverläßige Nachricht von den Büchern der Privilegirten Buchhandlung des Waysenhauses zu Züllichau, nach deren Inhalt, Absicht und Nutzen hinlänglich ertheilet (Züllichau: Weisenhaus, 1740), 79. 
local customs, which Schmidt explained at length, and in reference to natural knowledge which, in his view, when contrasted with the 18th century scholarship, withstands any scrutiny. Science thus should be enlisted in the service of theology, the rationality of science should not be treated as a potential enemy of religion since reason is in no conflict with Christianity, because "what is truly Christian is also supremely rational (hochvernünffig)"'147.

The understanding of natural events and phenomena enhanced the understanding of the Bible also in that metaphors that include such events can be better understood. The Biblical text thus does not have to be, and should not be, always understood literally. So, it is possible that the interpretation of the Bible can vary depending on the level of natural knowledge. This knowledge also allows for seeing miracles as supernatural phenomena, the province of the Biblical hyperphysicus, which Schmidt discussed in the last chapter of his Physicus. On the other hand, how about the Biblical text? In that respect, Schmidt could not settle on a consistent view. As mentioned, in the Historicus, Schmidt viewed the Biblical text as recorded under the direct divine supervision ${ }^{148}$, and thus inerrant and yet scribes could make mistakes ${ }^{149}$. However, in the Mathematicus he stated that "true theology does not allow an introduction of such corruption [as writing 40 instead of 4], even in the smallest points of the foundational text"150: no scribal errors are possible.

Schmidt was a pastor, not an active scholar or a physician, and in all his information he relied on the published scholarly literature. He listed his sources for his books, sometimes even for particular parts of his books and he referred to his sources in footnotes. However, it is never clear how much information comes from particular sources. As it turns out he did not use his sources as references, but he simply copied entire paragraphs or even pages never indicating them as quotations ${ }^{151}$. This is particularly visible in the Physicus in which he used two voluminous works written in Latin from which he extensively included translated fragments ${ }^{152}$. His third source of the Physicus was Scheuchzer, Schmidt's favorite scholar who made an appearance in all his compendia. However, the readers almost certainly would not notice it (and none of the reviews mentioned plagiarism) and if they did, they may not have been concerned about it satisfied with the fact of having in one book information culled from variety of sources and focusing on the spiritual message that Schmidt wanted to convey.

\footnotetext{
147 Johann Jacob Schmidt, Christlich-vernünffige Gedancken von dem Natürlichen Lebens-Ziel, und der Praedestination (Züllichau: Gottlob Benj[amin] Frommann, 1733), 2.

148 Schmidt, Biblischer historicus, 615.

149 Schmidt, Biblischer historicus, 252.

150 Schmidt, Biblischer mathematicus, 60.

151 The sources of some of his quotations are indicated above in the footnotes in this article.

152 Samuel Bochart, Hierozoicon (Londini: Roycroft Martyn, 1663); Matthaeus Hiller, Hierophyticon (Trajecti ad Rhenum: Ex libraria J. Broedelet, 1725).
} 


\section{Bibliography}

Bochart, Samuel. Hierozoicon. Londini: Roycroft Martyn, 1663.

Dehmel, Gisela. Die Arzneimittel in der Physikotheologie. Münster: Lit Verlag, 1996.

Eckart, Wolfgang. "Die Wissenschftstheologie des Johann Jacob Schmid (1691-1762): Anmerkungen zur Literaturgeschichte Ostpommerns". Pommern: Kunst, Geschichte, Volkstum 20, 4 (1982): 1-9.

[Frommann, Gottlob Benjamin]. Zuverläßige Nachricht von den Büchern der Privilegirten Buchhandlung des Waysenhauses zu Züllichau, nach deren Inhalt, Absicht und Nutzen hinlänglich ertheilet, Züllichau: Weisenhaus, 1740.

Hiller, Matthaeus. Hierophyticon. Trajecti ad Rhenum: Ex libraria J. Broedelet, 1725.

Hocker, Johann L. Mathematische Seelen-Lust. Frankfurt: Samuel Tobias Hocker, 1712.

Hübner, Johann. Curieuses und reales Natur-Kunst-Berg- Gewerck- und Sadlungs-Lexicon. [Leipzig]: Joh[ann] Fried[rich] Gleditsch, 1714.

Moser, Johann J. Des Lexici der jetztlebenden Lutherisch- und Reformirten Theologen in und um Teutschland, zweyter Theil. Züllichau: Benjamin Gottlob Frommann, 1741.

Richter, Christian F. Die höchstnöthige Erkenntniß des Menschen. Leipzig: Jo[hann] Fried[rich] Gleditsch, 1710.

Schmidt, Johann Jacob. Biblischer geographus. Züllichau: Gottlob Benjamin Frommann, 1740.

Schmidt, Johann J. Biblischer historicus. Leipzig: Jacob Schuster, 1740.

Schmidt, Johann J. Biblischer mathematicus. Züllichau: Gottlob Benjamin Frommann, 1736.

Schmidt, Johann J. Biblischer medicus. Züllichau: Johann Jacob Dendeler, 1743.

Schmidt, Johann J. Biblischer physicus. Leipzig: Jacob Schuster, 1748.

Schmidt, Johann J. Christlich-vernünfftige Gedancken von dem Natürlichen Lebens-Ziel, und der Praedestination. Züllichau: Gottlob Benj[amin] Frommann, 1733.

Trinius, Johann A. Beytrag zu einer Geschichte berühmter und verdienter Gottesgelehten. Leipzig: Carl Ludwig Jacobi, 1751. 